\title{
CONCENTRATES MADE FROM LEGUME SEEDS (LUPINUS ANGUSTIFOLIUS, LUPINUS LUTEUS AND PISUM SATIVUM) AND RAPESEED MEAL AS PROTEIN SOURCES IN LAYING HEN DIETS*
}

\author{
Andrzej Rutkowski ${ }^{\star}$, Sebastian A. Kaczmarek ${ }^{1}$, Marcin Hejdysz $^{1}$, Sebastian Nowaczewski², \\ Dorota Jamroz ${ }^{3}$
}

\author{
${ }^{1}$ Department of Animal Nutrition and Feed Management, \\ ${ }^{2}$ Department of Poultry Science, \\ Poznan University of Life Sciences, Wołyńska 33, 60-637 Poznań, Poland \\ ${ }^{3}$ Department of Animal Nutrition and Feed Quality, \\ Wrocław University of Environmental anf Life Sciences, J. Chełmońskiego 38c, 51-630 Wrocław, Poland \\ •Corresponding author: rutkowski@jay.au.poznan.pl
}

\begin{abstract}
The aim of the study was to determine the usefulness of two protein concentrates composed of rapeseed meal and new cultivars of narrow-leaved and yellow lupine, peas in laying hen diets and their influence on birds' performance and egg characteristics. The experiment was conducted with 180 layers kept in individual cages. The birds were randomly assigned to three treatments, with 60 hens in each and during the period of 17 weeks, they were fed diets: I - containing soybean meal as a protein source, II - containing protein concentrates composed of mixture of lupines, peas $\mathbf{( 1 9 . 4 8 \%}$ of diet) and rapeseed meal, III - containing protein concentrates composed of a mixture of lupines and peas $(27.68 \%$ of diet). The body weight, laying rate, egg weight, feed intake and feed conversion ratio (FCR) and egg characteristics were registered. After 9 weeks of experiment, a decrease of laying rate was recorded in treatment III. The mean value of laying rate for 17 weeks amounted to 82.7 (I), 82.5 (II) and $75.9 \%$ (III) $(\mathrm{P}<0.01)$. The egg weight was diversified already after 4 weeks of egg production and averaged 57.9 (I), 55.9 (II) and $54.9 \mathrm{~g}$ (III) (P<0.05). Feed intake amounted to 108 (I), 111 (II) and $104 \mathrm{~g}$ per hen/day (III), and FCR was 2.05, 3.17 and 2.23 $\mathrm{kg} / \mathrm{kg}$ egg weight, respectively. As to egg characteristics, increases of white index $(\mathrm{P}<0.05), \mathrm{Haugh}$ unit score and yolk colour in treatment III were observed but egg shell thickness was found significantly reduced. In conclusion, the use of about $\mathbf{2 7 . 6 8 \%}$ of legume seed in laying hen diet affected negatively performance results but about $19.48 \%$ of these seeds and $8 \%$ rapeseed meal in diets could be accepted as a soybean meal substitute.
\end{abstract}

Key words: lupine seeds, peas, performance, layers

Soybean meal constitutes the main dietary protein source in poultry feeding. Laying hen diets may contain about 20-25\% and growing bird feeds more than $30 \%$ soybean. Soya, derived mainly from Brazil or the USA, is mostly genetically modified giving rise to strong protests of poultry product consumers in many countries.

* Supported by funds from the program "Improvement of native plant protein feeds, their production, trade turnover and utilization in animal feed" of the Ministry of Agriculture and Rural Development of Poland. 
Although according to other authors, soya (GMO) has no negative influence on animal organisms (Świątkiewicz and Arczewska-Włosek, 2011).

Complete substitution of soybean meal in poultry feeds is difficult due to low protein concentration or/and high anti-nutrient content in lupines and pea seeds (Castanon and Perez-Lanzac, 1990; Fru-Nji et al., 2007; Nalle et al., 2011). Nevertheless, in recent years, the interest in the use of native legume seeds as protein components in diets for monogastric animals increased again (Perez-Maldonado et al., 1999; Jul et al., 2003; Diaz et al., 2005; Sujak et al., 2006; Laudadio and Tufarelli, 2011).

The area of cultivation of legume plants: field beans, narrow-leaved lupine ( $\mathrm{Lu}$ pinus angustifolius L.), yellow lupine (Lupinus luteus L.), white lupine (Lupinus albus L.) or peas (Pisum sativum L.) is currently low in Poland. However, the relative high crude protein level in these feeds is about 30-40\% in lupine and $20-30 \%$ in other legume seeds (pea, faba bean) (Perez-Maldonado et al., 1999; Diaz et al., 2005; Smulikowska and Rutkowski, 2005; Duranti, 2006; Martinez-Villaluenga et al., 2006; Jamroz and Kubizna, 2008; Nalle et al., 2011).

The nutritive value of legume seeds, especially of lupines, is restricted by the activity of naturally occurring antinutritive substances which are recognized as harmful factors, i.e. oligosaccharides, trypsin inhibitors, alkaloids, tannins, phytoestrogens, inositol phosphates, lectins and saponins (Zduńczyk et al., 1998; Wasilewko and Buraczewska, 1999; Buckeridge et al., 2000; Miecznikowska et al., 2004; Martinez-Villaluenga et al., 2006; Erdemouglu and Ozkan, 2007; Guillamon et al., 2008; Jamroz and Kubizna, 2008). However, some of these constituents of leguminous plants, tocopherols and tannins, show a beneficial activity as antioxidants (Lampart-Szczapa et al., 2003; Duranti, 2006; Martinez-Villaluenga et al., 2006; Erdemouglu and Ozkan, 2007; Viveros et al., 2007; Jamroz and Kubizna, 2008). Legume proteins are rich in lysine, although poor in methionine and isoleucine. Oligosaccharides from the raffinose family, small amounts of tannins or lectins participate in regulation of microbial populations in the digestive tract and in the immune response of organisms (Jul et al., 2003; Erdemouglu and Ozkan, 2007; Jamroz and Kubizna, 2008). Seeds, particularly those of lupines, are rich in microelements (Sandberg, 2002) and antioxidants, namely tocopherol (Lampart-Szczapa et al., 2003; Viveros et al., 2007).

Investigations concerning the use of legume seeds in laying hen and broiler diets have a long tradition and the number of published results is considerable, although the inclusion of different cultivars of those feeds in diet has in many cases decreased the performance results in poultry (Castanon and Perez-Lanzac, 1990; Igbasan and Guenter, 1997; Hughes and Kocher, 1998; Perez-Maldonado et al., 1999; McNeill et al., 2004; Diaz et al., 2005; Hammershøj and Steenfeldt, 2005; Orda et al., 2006; Fru-Nji et al., 2007; Laudadio and Tufarelli, 2011).

Rapeseed and its byproducts have a high pectin content and complex fibre matrix structure, which results in its high water-holding capacity and poor nutrient availability for monogastric animals, including poultry. But due to high soybean meal prices, there is growing interest within the feed industry in using rapeseed byproducts in poultry feeding (Mikulski et al., 2012) and full-fat oilseeds in poultry diets (Rutkowski et al., 2012). According to the above authors, rapeseed and its byproducts could be a valuable source of energy and protein for poultry. 
The aim of the study was to evaluate the effect of replacement of soybean meal with a mixture of narrow-leaved or yellow lupine and pea seeds in hen diets on performance and egg quality.

\section{Material and methods}

\section{Animals and diets}

One hundred eighty Hy-line Brown hens at the age of 17 weeks were weighed, placed in individual cages and fed pre-laying diets based on wheat, maize and soybean meal and containing $16 \%$ crude protein and $11 \mathrm{MJ} \mathrm{ME} / \mathrm{kg}$. Before the beginning of the laying period, the birds were randomly assigned to three treatments, each with 60 hens. The birds had free access to drinking water and feed. The lighting program was $14 \mathrm{~h}$ of light and $10 \mathrm{~h}$ of darkness.

Table 1. Composition of concentrates

\begin{tabular}{|c|c|c|}
\hline \multirow{2}{*}{ Components $(\%)$} & \multicolumn{2}{|c|}{ Concentrate } \\
\hline & $\mathrm{I}$ & II \\
\hline Yellow lupine & 5.07 & 23.70 \\
\hline Narrow-leaved lupine & 22.22 & 22.22 \\
\hline Peas & 15.56 & 11.11 \\
\hline Rapeseed meal & 17.90 & - \\
\hline Maize & - & 4.44 \\
\hline Rapeseed oil & 13.30 & 12.22 \\
\hline Limestone & 18.87 & 18.89 \\
\hline Dicalcium phosphate & 2.89 & 3.11 \\
\hline Vitamin-mineral premix ${ }^{1}$ & 1.11 & 1.11 \\
\hline $\mathrm{NaHCO}_{3}$ & 0.89 & 0.78 \\
\hline $\mathrm{NaCl}$ & 0.38 & 0.36 \\
\hline DL-Methionine & 0.40 & 0.47 \\
\hline L-Lysine & 0.56 & 0.56 \\
\hline Threonine & 0.42 & 0.43 \\
\hline Tryptophan & 0.10 & 0.09 \\
\hline L-Valine & 0.33 & 0.51 \\
\hline Metabolizable energy (MJ/kg) & 10.64 & 10.64 \\
\hline Crude protein $(\%)$ & 19.28 & 19.30 \\
\hline $\mathrm{Ca}(\%)$ & 8.20 & 8.19 \\
\hline P-available (\%) & 0.73 & 0.74 \\
\hline $\mathrm{Na}(\%)$ & 0.40 & 0.37 \\
\hline $\mathrm{Cl}(\%)$ & 0.36 & 0.36 \\
\hline Lys (\%) & 1.46 & 1.45 \\
\hline Met+Cys (\%) & 0.99 & 0.98 \\
\hline Try (\%) & 0.28 & 0.27 \\
\hline $\operatorname{Thr}(\%)$ & 1.15 & 1.13 \\
\hline Val (\%) & 1.23 & 1.24 \\
\hline $\operatorname{Arg}(\%)$ & 1.61 & 1.66 \\
\hline Linol. acid (\%) & 3.36 & 3.34 \\
\hline
\end{tabular}

${ }^{1}$ Provided per kg diet: vit. A $10000 \mathrm{IU}$, vit. $\mathrm{D}_{3} 2000 \mathrm{IU}$, vit. E $20 \mathrm{mg}$, vit. $\mathrm{K}_{3} 1.5 \mathrm{mg}$, vit. $\mathrm{B}_{1} 1 \mathrm{mg}$, vit. $\mathrm{B}_{2}$ $4 \mathrm{mg}$, vit. $\mathrm{B}_{3} 20 \mathrm{mg}$, vit. $\mathrm{B}_{5} 8 \mathrm{mg}$, vit. $\mathrm{B}_{6} 1.5 \mathrm{mg}$, vit. $\mathrm{B}_{9} 0.8 \mathrm{mg}$, choline $200 \mathrm{mg}, \mathrm{Fe} 45 \mathrm{mg}, \mathrm{Mn} 90 \mathrm{mg}, \mathrm{Cu} 8 \mathrm{mg}$, $\mathrm{Zn} 60 \mathrm{mg}$, I $1 \mathrm{mg}$, Co $0.5 \mathrm{mg}$, Se $0.25 \mathrm{mg}$, antioxidant $15 \mathrm{mg}$, vit. $\mathrm{B}_{12} 3300 \mathrm{mcg}$, biotin $50 \mathrm{mg}$. 
Experimental diets were isoproteic and energetic and containing about $16.0 \%$ crude protein, 11.3 MJ ME/kg feed but differed in plant protein components. Control diet contained soybean meal as a protein source. The diets for treatment II and III consisted of protein concentrates, which accounted for $45 \%$ of the diet (Table 1). Protein concentrates were designed to provide high quality protein (amino acid composition) and minimal level of antinutrients. In the protein concentrate I, the following protein components were used: rapeseed meal (8\%), narrow-leaved lupine (Lupinus angustifolius) cv. Boruta (10\%), 2\% yellow lupine cv. Mister and about $8 \%$ pea cv. Muza. In the protein concentrate II, yellow lupine (12\%), narrow-leaved lupine $(10 \%)$ and about $5 \%$ peas were used. The content of individual legumes depended on the amino acid content in these components and calculation and balancing of the amino acid level in the feed mixtures. The characteristics of chemical composition of the applied legume seeds and concentrates are presented in Table 3, the diet composition is shown in Table 2.

Table 2. Composition of experimental diets

\begin{tabular}{l|c|c|c}
\hline \multirow{2}{*}{ Components (\%) } & \multicolumn{3}{c}{ Treatments - diets } \\
\cline { 2 - 4 } & I & II & III \\
\cline { 2 - 4 } & control & $19.48 \%$ legumes & $27.68 \%$ legumes \\
\hline Maize & 12.71 & - & - \\
Wheat & 55.0 & 55.0 & 55.0 \\
Concentrate I & - & 45 & - \\
Concentrate II & - & - & 45 \\
Soybean meal & 18.02 & - & - \\
Rapeseed oil & 3.24 & - & - \\
Limestone & 8.59 & - & - \\
Dicalcium phosphate & 1.14 & - & - \\
Vitamin-mineral premix & 0.5 & - & - \\
NaHCO & 0.305 & - & - \\
NaCl & 0.152 & - & - \\
DL-Methionine & 0.155 & - & - \\
L-Lysine & 0.135 & - & - \\
Threonine & 0.046 & - & - \\
Tryptophan & 0.002 & - & 11.3 \\
Metabolizable energy (MJ/kg) & 11.3 & 11.3 & 3.5 \\
Crude protein (\%) & 16.2 & 15.8 & 0.39 \\
Ca (\%) & 3.5 & 3.5 & 0.16 \\
P-available (\%) & 0.39 & 0.39 & 0.16 \\
Na (\%) & 0.16 & 0.16 & 0.77 \\
Cl (\%) & 0.16 & 0.16 & 0.68 \\
Lys (\%) & 0.75 & 0.75 & 0.16 \\
Met+Cys (\%) & 0.63 & 0.64 & 0.53 \\
Try (\%) & 0.16 & 0.16 & 0.54 \\
Thr (\%) & 0.53 & 0.53 & 2.03 \\
Val (\%) & 0.68 & 0.61 & - \\
Arg (\%) & 0.96 & 1.05 & - \\
Linol. acid (\%) & 1.56 & 2.01 & - \\
\hline
\end{tabular}

Provided per kg diet: vit. A $10000 \mathrm{IU}$, vit. $\mathrm{D}_{3} 2000 \mathrm{IU}$, vit. E $20 \mathrm{mg}$, vit. $\mathrm{K}_{3} 1.5 \mathrm{mg}$, vit. B $1 \mathrm{mg}$, vit. B $4 \mathrm{mg}$, vit. $\mathrm{B}_{3} 20 \mathrm{mg}$, vit. $\mathrm{B}_{5} 8 \mathrm{mg}$, vit. $\mathrm{B}_{6} 1.5 \mathrm{mg}$, vit. $\mathrm{B}_{9} 0.8 \mathrm{mg}$, choline $200 \mathrm{mg}$, Fe $45 \mathrm{mg}, \mathrm{Mn} 90 \mathrm{mg}, \mathrm{Cu} 8 \mathrm{mg}$, Zn $60 \mathrm{mg}$, I $1 \mathrm{mg}$, Co $0.5 \mathrm{mg}$, Se $0.25 \mathrm{mg}$, antioxidant $15 \mathrm{mg}$, vit. $\mathrm{B}_{12} 3300 \mathrm{mcg}$, biotin $50 \mathrm{mg}$. 
Table 3. Chemical composition of legume seeds, in DM

\begin{tabular}{|c|c|c|c|}
\hline Item & Narrow-leaved lupine cv. Boruta & Yellow lupine cv. Mister & Pea cv. Muza \\
\hline Dry matter (\%) & 88.62 & 89.01 & 86.65 \\
\hline Crude ash $(\%)$ & 3.78 & 4.15 & 3.14 \\
\hline Crude protein $(\%)$ & 36.88 & 38.98 & 27.57 \\
\hline Crude fiber $(\%)$ & 15.09 & 19.23 & 6.34 \\
\hline $\mathrm{ADF}(\%)$ & 21.43 & 24.24 & 7.97 \\
\hline NDF (\%) & 25.92 & 28.24 & 13.88 \\
\hline Crude fat $(\%)$ & 5.81 & 5.26 & 1.32 \\
\hline Starch $(\%)$ & - & - & 44.23 \\
\hline Gross energy (MJ/kg) & 20.73 & 20.49 & 19.45 \\
\hline Viscosity (cP) & 1.21 & 1.09 & 1.29 \\
\hline \multicolumn{4}{|l|}{ Amino acid (\% protein) } \\
\hline Asp & 8.91 & 8.81 & 10.49 \\
\hline Thr & 3.15 & 3.17 & 3.54 \\
\hline Ser & 4.11 & 4.24 & 4.38 \\
\hline Glut & 23.77 & 24.46 & 19.46 \\
\hline Pro & 6.52 & 6.08 & 5.77 \\
\hline Gly & 4.01 & 3.47 & 3.83 \\
\hline Ala & 3.33 & 2.83 & 3.81 \\
\hline Val & 3.72 & 3.17 & 4.35 \\
\hline Iso & 3.68 & 3.20 & 3.66 \\
\hline Leu & 6.64 & 6.50 & 6.63 \\
\hline Tyr & 3.07 & 3.24 & 3.26 \\
\hline Phe & 3.46 & 4.24 & 5.00 \\
\hline His & 2.91 & 3.32 & 3.37 \\
\hline Lys & 4.49 & 4.76 & 6.52 \\
\hline Arg & 11.65 & 10.12 & 8.82 \\
\hline Total & 39.39 & 39.29 & 42.53 \\
\hline \multicolumn{4}{|l|}{ Minerals ( $g / k g D M)$} \\
\hline $\mathrm{Ca}$ & 3.33 & 2.95 & 1.27 \\
\hline $\mathrm{K}$ & 13.45 & 12.66 & 12.72 \\
\hline$P$ & 6.84 & 7.47 & 5.10 \\
\hline $\mathrm{Na}$ & 0,08 & 0.08 & 0.062 \\
\hline $\mathrm{Mg}$ & 2,10 & 3.14 & 1.47 \\
\hline $\mathrm{Mn}$ & 0.13 & 0.08 & 0.02 \\
\hline $\mathrm{Cu}$ & 0.04 & 0.02 & 0.02 \\
\hline $\mathrm{Fe}$ & 0.07 & 0.13 & 0.07 \\
\hline $\mathrm{Zn}$ & 0.07 & 0.07 & 0.06 \\
\hline \multicolumn{4}{|l|}{ Antinutrients } \\
\hline Total alkaloid (TA) (mg/kg) & 440 & 270 & - \\
\hline Angustifoline (\% of TA) & 12.54 & - & - \\
\hline Isolupanine ( $\%$ of TA) & 4.56 & - & - \\
\hline Lupanine ( $\%$ of TA) & 56.17 & - & - \\
\hline $130 \mathrm{H}$ lupanine (\% of TA) & 26.73 & - & - \\
\hline Sparteine ( $\%$ of TA) & - & 33.6 & - \\
\hline Lupinine ( $\%$ of TA) & - & 63.29 & - \\
\hline Oligosaccharide (g/kg) & 8.77 & 8.56 & 8.34 \\
\hline Rafinose (g/kg) & 1.20 & 1.10 & 0.90 \\
\hline Stachiose (g/kg) & 5.61 & 4.94 & 3.86 \\
\hline Verbascose (g/kg) & 1.96 & 2.53 & 3.59 \\
\hline P phyt. (\%) & 0.42 & 0.70 & 0.44 \\
\hline P phyt./P total & 61 & 75 & 62 \\
\hline
\end{tabular}




\section{Analytical methods}

For chemical analysis, the representative samples of seeds were ground to pass through a $0.5 \mathrm{~mm}$ sieve. Seeds were analyzed in duplicate for dry matter (DM), crude protein $(\mathrm{CP})$, ether extract (EE), crude fiber (CF), crude ash (CA), acid detergent fiber (ADF) and neutral detergent fiber (NDF) using methods 934.01, 976.05, 920.39, 978.10, 942.05, 973.18 respectively, according to AOAC (2007).

The amino acid content was determined using a type AAA-400 Automatic Amino Acid Analyzer employing ninhydrin for post-column derivatization. Before the analysis, samples were hydrolyzed with $6 \mathrm{~N} \mathrm{HCl}$ for $24 \mathrm{~h}$ at $110^{\circ} \mathrm{C}$ (procedure 994.12; AOAC (2007)). Sugars were analyzed according to PN-R-64784 method. Gross energy was determined using an adiabatic bomb calorimeter (KL 12Mn, Precyzja-Bit PPHU, Poland) standardized with benzoic acid. Mineral composition (Ca, P, Na, K, $\mathrm{Zn}, \mathrm{Mg}, \mathrm{Cu}, \mathrm{Mn}, \mathrm{Fe}$ ) was analyzed by ICP-OES (P.10I35-ICP method) after microwave mineralization.

Lupine alkaloids were extracted from flour by trichloroacetic acid and methylene chloride. The determination was provided by gas chromatography method (Shimadzu GC17A) with a capillary column (Phenomenex). Raffinose family oligosaccharides (RFO) were extracted and analyzed by high-resolution gas chromatography as described previously by Zalewski et al. (2001). Phytate content was analyzed according to AOAC (2007) (methods 986.11) after extraction in $\mathrm{HCl}$ and by the use of bipiridine. The absorbance was measured with Spectrophotometer Marcel at wavelength of $519 \mathrm{~nm}$.

\section{Performance and egg quality}

At the beginning of the experiment, laying hens were at the age of 21 weeks. The laying performance was recorded weekly in the period of 17 weeks of experiment for each of randomly selected 60 hens per treatment. The length of this period was associated with an attempt to establish the moment at which positive or negative effects of protein sources on the above mentioned variable could be seen. The feed consumption was registered in the same way. The average egg weight was determined also weekly on the basis of randomly collected 30 eggs from each treatment. Mortality was recorded daily.

In the fifth and thirteenth weeks of the experiment 30 eggs from each treatment and time were randomly selected. The egg quality was determined by taking into consideration the following parameters:

- Egg weight (g) with $0.01 \mathrm{~g}$ accuracy with the assistance of the WPS 360C type balance,

- Yolk colour (points) was measured visually using Roche Yolk Colour Fan from 1 (the lightest) to 15 (the darkest) points of scale,

- White index (\%) was calculated according to the formula:

White index $=$ thick egg white height $(\mathrm{mm}) \times 100 /$ thick white width $(\mathrm{mm})$,

- Haugh units were calculated according to the formula:

$$
H U=100 \log \left(h-1.7 W^{0.37}+7.6\right)
$$


where:

$H U$ - Haugh unit score,

$h$ - average thick white height $(\mathrm{mm})$,

$W$ - egg weight (g).

- Eggshell thickness $(\mu \mathrm{m})$ together with shell membranes at the sharp, blunt and equatorial part of the egg using a screw micrometer for this purpose.

\section{Statistical analysis}

Statistical calculations were performed using $\mathrm{SAS}^{\circledR}$ v.9.1 package. Mean values as well as the standard error of the mean (SEM) were calculated for all traits. Differences among treatments with regard to egg quality traits were determined employing the two-way linear model of ANOVA:

$$
Y_{i j k}=\alpha_{j}+\beta_{k}+(\alpha \beta)_{j k}+e_{i j k}
$$

where:

$Y_{i j k}$ is value of the analyzed trait,

$\alpha_{i}$ is constant effect of $\mathrm{i}^{\text {th }}$ group of hens (i=I, II, III),

$\beta_{k}$ is constant effect of $\mathrm{j}^{\mathrm{th}}$ week $(\mathrm{j}=5,13)$,

$(\alpha \beta)_{j k}$ is interaction between $\alpha$ and $\beta$,

$e_{i j k}$ is effect of experimental error.

For all traits, the significance of differences between groups of hens was verified using Fisher's test. Differences between weeks, within groups, were determined by the Student t-test.

\section{Results}

The health status of hens during the entire experimental time was good and without visible disease symptoms and mortality cases. The initial body weight of hens amounted in treatments to about $1.75 \mathrm{~kg}$ and at the end of experiment it was 1.88 , 1.89 and $1.69 \mathrm{~kg}$, respectively, in individual treatments $(\mathrm{P} \leq 0.004)$.

From the tenth week on, the egg production was significantly $(\mathrm{P}<0.01)$ lower in treatment III (75.9\%) in comparison with the laying rate of hens fed the control diet $(82.7 \%)$ or the diet containing about $19.48 \%$ legume seeds and $8 \%$ rapeseed meal $(82.5 \%)$ (Table 4$)$.

The significant variability of egg weight among treatments was noted. At the beginning of the seventh week, the egg weight of hens from the control treatment (I) was significantly higher $(\mathrm{P}<0.01)$ than of eggs derived from the experimental treatments (II and III) (Table 5).

For feed consumption (Table 6), irregular variability was observed; however, in the majority of weeks, hens fed diets with greater legume seed content (diet III) consumed lower amounts of feed mixture. Mean values of this parameter calculated for 
17 weeks varied non-significantly in treatments I and II, while in treatment III they were lower than in control treatment $(\mathrm{P}<0.05)$.

Table 4. Laying rate of hens during first 17 weeks of egg production, $\%$

\begin{tabular}{l|c|c|c|c|c}
\hline \multirow{2}{*}{ Weeks } & \multicolumn{3}{|c|}{ Treatments } & \multirow{2}{*}{ SEM } & \multirow{2}{*}{ P-Value } \\
\cline { 2 - 4 } 1 & $\mathrm{I}$ & $\mathrm{II}$ & $\mathrm{III}$ & 0.42 & 0.799 \\
2 & 0.71 & 0.48 & 1.19 & 1.03 & 0.059 \\
3 & 17.86 & 12.38 & 16.91 & 1.83 & 0.711 \\
4 & 67.14 & 64.52 & 63.33 & 1.32 & 0.115 \\
5 & 92.86 & 89.05 & 86.19 & 1.01 & 0.313 \\
6 & 95.00 & 97.38 & 93.57 & 0.72 & 0.563 \\
7 & 96.19 & 97.62 & 95.71 & 1.25 & 0.623 \\
8 & 97.14 & 95.95 & 94.05 & 1.56 & 0.572 \\
9 & 95.48 & 96.43 & 91.19 & 1.38 & 0.272 \\
10 & 95.48 & 96.43 & 91.19 & 1.20 & 0.015 \\
11 & $95.24 \mathrm{a}$ & $96.43 \mathrm{a}$ & $89.05 \mathrm{~b}$ & 2.18 & 0.032 \\
12 & $91.19 \mathrm{ab}$ & $97.14 \mathrm{a}$ & $83.81 \mathrm{~b}$ & 1.69 & 0.017 \\
13 & $91.67 \mathrm{a}$ & $95.95 \mathrm{a}$ & $85.00 \mathrm{~b}$ & 1.46 & 0.006 \\
14 & $93.81 \mathrm{~A}$ & $95.71 \mathrm{~B}$ & $85.95 \mathrm{~B}$ & 2.12 & 0.037 \\
15 & $94.29 \mathrm{a}$ & $89.76 \mathrm{ab}$ & $81.67 \mathrm{~b}$ & 2.87 & $<.0001$ \\
16 & $92.62 \mathrm{~A}$ & $90.48 \mathrm{~A}$ & $69.76 \mathrm{~B}$ & 2.0001 \\
17 & $94.52 \mathrm{~A}$ & $90.24 \mathrm{~A}$ & $78.10 \mathrm{~B}$ & 2.01 & 0.001 \\
Mean & $95.48 \mathrm{~A}$ & $97.86 \mathrm{~A}$ & $83.81 \mathrm{~B}$ & 1.93 & 0.004 \\
\hline
\end{tabular}

The differences among means for treatments in rows designated with $\mathrm{a}, \mathrm{b}-$ significant at $\mathrm{P}<0.05 ; \mathrm{A}, \mathrm{B}-$ significant at $\mathrm{P}<0.01$.

Table 5. Changes of egg weight during first 17 weeks of egg production, $\mathrm{g}$

\begin{tabular}{|c|c|c|c|c|c|}
\hline \multirow{2}{*}{ Weeks } & \multicolumn{3}{|c|}{ Treatments } & \multirow{2}{*}{ SEM } & \multirow{2}{*}{ P-Value } \\
\hline & $\mathrm{I}$ & II & III & & \\
\hline 1 & 47.50 & 57.00 & 47.60 & 3.83 & 0.634 \\
\hline 2 & 51.25 & 48.00 & 48.28 & 1.12 & 0.449 \\
\hline 3 & $50.66 \mathrm{a}$ & $49.10 \mathrm{~b}$ & $49.00 \mathrm{~b}$ & 0.31 & 0.036 \\
\hline 4 & 51.27 & 52.19 & 52.53 & 0.82 & 0.829 \\
\hline 5 & 55.68 & 51.69 & 51.38 & 1.35 & 0.370 \\
\hline 6 & 56.91 & 55.49 & 55.03 & 0.37 & 0.095 \\
\hline 7 & $58.69 \mathrm{~A}$ & $56.58 \mathrm{~B}$ & $56.81 \mathrm{~B}$ & 0.38 & 0.010 \\
\hline 8 & $59.39 \mathrm{a}$ & $57.58 \mathrm{ab}$ & $56.71 \mathrm{~b}$ & 0.44 & 0.026 \\
\hline 9 & $59.45 \mathrm{a}$ & $57.66 \mathrm{ab}$ & $57.03 \mathrm{~b}$ & 0.42 & 0.037 \\
\hline 10 & 59.83 & 58.26 & 57.61 & 0.51 & 0.186 \\
\hline 11 & $59.48 \mathrm{a}$ & $57.60 \mathrm{ab}$ & $55.44 \mathrm{~b}$ & 0.74 & 0.039 \\
\hline 12 & 60.33 & 56.21 & 56.20 & 0.91 & 0.096 \\
\hline 13 & $60.82 \mathrm{~A}$ & $57.03 \mathrm{~B}$ & $57.63 \mathrm{~B}$ & 0.57 & 0.005 \\
\hline 14 & $61.09 \mathrm{a}$ & $58.25 \mathrm{ab}$ & $56.79 \mathrm{~b}$ & 0.68 & 0.019 \\
\hline 15 & $61.09 \mathrm{~A}$ & $58.21 \mathrm{~B}$ & $56.71 \mathrm{~B}$ & 0.63 & 0.006 \\
\hline 16 & $62.24 \mathrm{~A}$ & $60.24 \mathrm{~A}$ & $55.85 \mathrm{~B}$ & 0.81 & 0.001 \\
\hline 17 & $61.85 \mathrm{a}$ & $60.24 \mathrm{ab}$ & $58.05 \mathrm{~b}$ & 0.62 & 0.037 \\
\hline Mean & $57.92 \mathrm{a}$ & $55.94 \mathrm{~b}$ & $54.99 \mathrm{~b}$ & 0.44 & 0.012 \\
\hline
\end{tabular}

The differences among means for treatments in rows designated with $\mathrm{a}, \mathrm{b}-$ significant at $\mathrm{P}<0.05 ; \mathrm{A}, \mathrm{B}-$ significant at $\mathrm{P}<0.01$. 
For feed conversion ratio per kg of eggs (Table 7) during the last three weeks of the experiment, differences among treatments were significant $(\mathrm{P}<0.05)$.

Table 6. Average feed intake during first 17 weeks of egg production, g/hen/week,

\begin{tabular}{l|c|c|c|c|c}
\hline \multirow{2}{*}{ Weeks } & \multicolumn{3}{c}{ Treatments } & \multirow{2}{*}{ SEM } & \multirow{2}{*}{ P-Value } \\
\cline { 2 - 4 } 1 & $\mathrm{I}$ & $\mathrm{II}$ & $\mathrm{III}$ & & 0.243 \\
2 & 79 & 86 & 84 & 1.63 & 0.047 \\
3 & $88 \mathrm{a}$ & $96 \mathrm{ab}$ & $105 \mathrm{~b}$ & 2.86 & 0.129 \\
4 & 95 & 100 & 94 & 1.24 & 0.674 \\
5 & 104 & 106 & 103 & 1.50 & 0.133 \\
6 & 99 & 104 & 99 & 1.31 & 0.003 \\
7 & $124 \mathrm{~A}$ & $124 \mathrm{~A}$ & $116 \mathrm{~B}$ & 1.23 & 0.074 \\
8 & 111 & 114 & 107 & 1.39 & 0.110 \\
9 & 117 & 120 & 112 & 1.57 & 0.038 \\
10 & $109 \mathrm{ab}$ & $112 \mathrm{a}$ & $102 \mathrm{~b}$ & 1.71 & 0.229 \\
11 & 116 & 119 & 112 & 1.56 & 0.236 \\
12 & 107 & 115 & 106 & 2.37 & 0.084 \\
13 & 114 & 117 & 108 & 1.72 & 0.122 \\
14 & 114 & 111 & 104 & 1.99 & 0.056 \\
15 & $107 \mathrm{ab}$ & $108 \mathrm{a}$ & $98 \mathrm{~b}$ & 1.92 & 0.003 \\
16 & $123 \mathrm{~A}$ & $116 \mathrm{~A}$ & $108 \mathrm{~B}$ & 2.18 & 0.043 \\
17 & $110 \mathrm{ab}$ & $115 \mathrm{a}$ & $105 \mathrm{~b}$ & 1.74 & 0.081 \\
Mean & 121 & 122 & 99 & 4.84 & 0.013 \\
\hline
\end{tabular}

The differences among means for treatments in rows designated with $\mathrm{a}, \mathrm{b}-$ significant at $\mathrm{P}<0.05 ; \mathrm{A}, \mathrm{B}-$ significant at $\mathrm{P}<0.01$.

Table 7. Feed conversion ratio during first 17 weeks of egg production, $\mathrm{kg} / \mathrm{kg}$ of egg weight

\begin{tabular}{l|c|c|c|c|c}
\hline \multirow{2}{*}{ Weeks } & \multicolumn{3}{|c|}{ Treatments } & \multirow{2}{*}{ SEM } & \multirow{2}{*}{ P-Value } \\
\cline { 2 - 4 } & I & II & III & & - \\
\hline 1 & - & - & - & - & - \\
3 & - & - & - & - & 0.199 \\
4 & 2.84 & 3.17 & 3.05 & 0.08 & 0.863 \\
5 & 2.22 & 2.29 & 2.28 & 0.06 & 0.293 \\
6 & 1.88 & 2.11 & 2.09 & 0.06 & 0.406 \\
7 & 2.26 & 2.29 & 2.29 & 0.03 & 0.083 \\
8 & 1.95 & 2.11 & 2.01 & 0.03 & 0.469 \\
9 & 2.08 & 2.18 & 2.17 & 0.03 & 0.639 \\
10 & 1.93 & 2.01 & 1.97 & 0.03 & 0.098 \\
11 & 2.04 & 2.12 & 2.19 & 0.03 & 0.004 \\
12 & $1.97 \mathrm{~A}$ & $2.07 \mathrm{~B}$ & $2.33 \mathrm{~B}$ & 0.05 & 0.277 \\
13 & 2.07 & 2.19 & 2.28 & 0.05 & 0.144 \\
14 & 2.00 & 2.02 & 2.11 & 0.02 & 0.117 \\
15 & 1.86 & 2.10 & 2.13 & 0.06 & $<.0001$ \\
16 & $2.19 \mathrm{~A}$ & $2.21 \mathrm{~A}$ & $2.73 \mathrm{~B}$ & 0.07 & $<.0001$ \\
17 & $1.88 \mathrm{~A}$ & $2.12 \mathrm{~B}$ & $2.41 \mathrm{C}$ & 0.06 & 0.043 \\
Mean & $2.05 \mathrm{a}$ & $2.07 \mathrm{a}$ & $2.35 \mathrm{~b}$ & 0.06 & 0.042 \\
\hline
\end{tabular}

The differences among means for treatments in rows designated with $\mathrm{a}, \mathrm{b}-$ significant $\mathrm{at} \mathrm{P}<0.05 ; \mathrm{A}, \mathrm{B}$, $\mathrm{C}$ - significant at $\mathrm{P}<0.01$. 


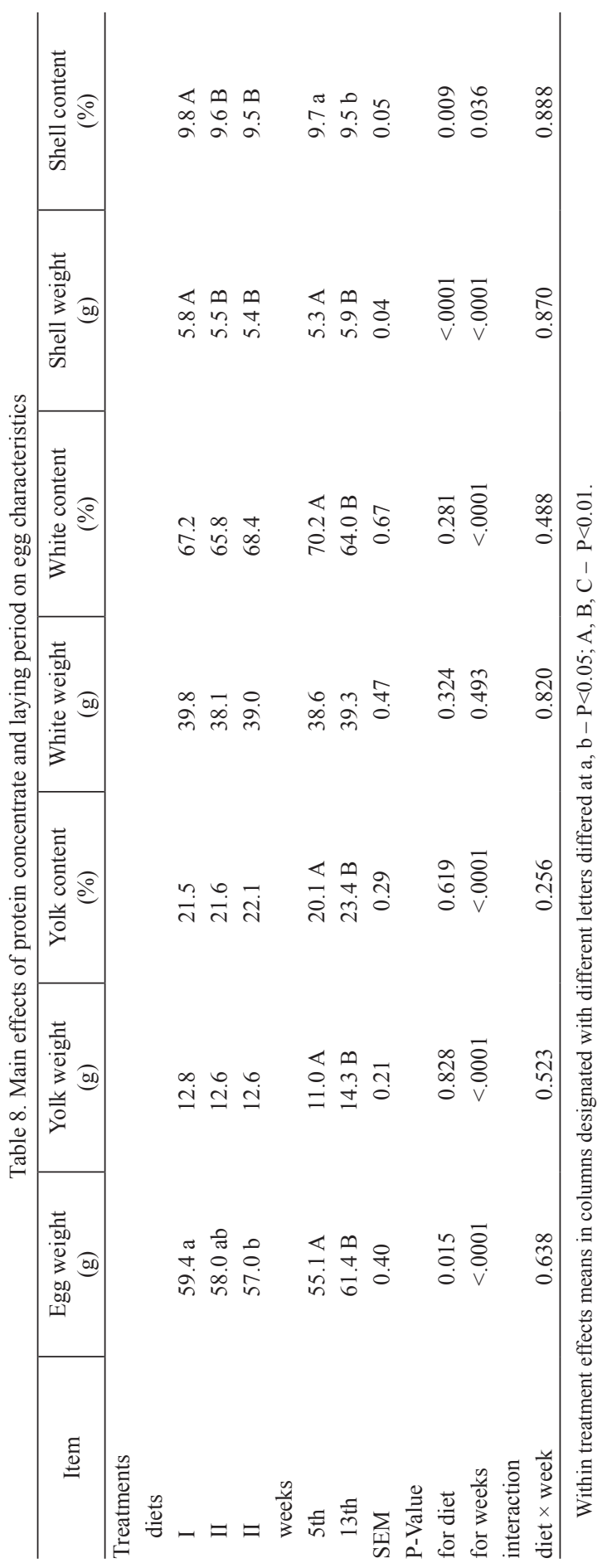


The used plant protein sources affected egg parameters. The increased legume seed content in the diets led to a decrease of egg weight $(57.0 \mathrm{~g})(\mathrm{P}<0.05)$ and shell weight $(5.3 \mathrm{~g})$ and their share in egg $(9.5 \%)$ compared to the control treatment $(\mathrm{P}<0.01)$ (Table 8). After 13 weeks of application of experimental diets, significant $(\mathrm{P}<0.01)$ increases in the egg and yolk weight and proportion were noted (Table 9).

Table 9. Main effects of protein concentrate and laying period on egg quality traits

\begin{tabular}{l|c|c|c|c|c}
\hline \multicolumn{1}{c|}{ Item } & $\begin{array}{c}\text { Yolk index } \\
(\%)\end{array}$ & $\begin{array}{c}\text { Yolk colour } \\
(\text { points })\end{array}$ & $\begin{array}{c}\text { White } \\
\text { index }(\%)\end{array}$ & $\begin{array}{c}\text { Haugh units } \\
(\text { points })\end{array}$ & $\begin{array}{c}\text { Shell thickness } \\
(\mu \mathrm{m})\end{array}$ \\
\hline $\begin{array}{l}\text { Treatments } \\
\text { diets }\end{array}$ & & & & \\
$\quad$ I & 48.6 & 13.3 & $10.3 \mathrm{~A}$ & $86.4 \mathrm{~A}$ & $370 \mathrm{~A}$ \\
$\quad$ II & 49.5 & 13.4 & $10.9 \mathrm{~A}$ & $88.7 \mathrm{~A}$ & $360 \mathrm{~B}$ \\
$\quad$ III & 49.9 & 13.5 & $12.0 \mathrm{~B}$ & $91.7 \mathrm{~B}$ & $354 \mathrm{~B}$ \\
weeks & & & & & \\
$\quad$ 5th & $52.1 \mathrm{~A}$ & $12.7 \mathrm{~A}$ & $12.5 \mathrm{~A}$ & $93.5 \mathrm{~A}$ & $357 \mathrm{~A}$ \\
$\quad$ 13th & $46.4 \mathrm{~B}$ & $14.0 \mathrm{~B}$ & $9.6 \mathrm{~B}$ & $84.3 \mathrm{~B}$ & $366 \mathrm{~B}$ \\
SEM & 0.30 & 0.07 & 0.20 & 0.65 & 1.77 \\
P-Value diets & 0.052 & 0.163 & 0.0004 & 0.0004 & 0.001 \\
Weeks & $<.0001$ & $<.0001$ & $<.0001$ & $<.0001$ & 0.008 \\
Interaction diet $\times$ week & 0.324 & 0.216 & 0.573 & 0.506 & 0.730 \\
\hline
\end{tabular}

The differences among means in columns designated with $\mathrm{a}, \mathrm{b}$ - significant at $\mathrm{P}<0.05 ; \mathrm{A}, \mathrm{B}, \mathrm{C}-$ significant at $\mathrm{P}<0.01$

Use of diet III increased $(\mathrm{P}<0.05)$ white index and HU score, but decreased $(\mathrm{P}<0.05)$ shell thickness in comparison with treatments I and II. Thirteen weeks of feeding hens with experimental diets caused an increase in yolk color $(\mathrm{P}<0.01)$ and a decrease in egg shell thickness $(\mathrm{P}<0.01)$.

\section{Discussion}

In the available literature, considerable variations in legume seed chemical composition, as well as their nutritional value depending on cultivars or varieties, as well as variation in content of antinutritive substances were previously reported (Zduńczyk et al., 1996; Igbasan and Guenter, 1997; Hughes and Kocher, 1998; Perez-Maldonado et al., 1999; Jul et al., 2003; Sujak et al., 2006; Fru-Nji et al., 2007; Laudadio and Tufarelli, 2011; Laudadio and Tufarelli, 2012).

The nutritional value of the used seeds of narrow-leaved lupine cv. Boruta was good when compared to older cultivars cultivated in Poland (Wasilewko and Buraczewska, 1999). Protein content amounted to about 37\% compared to $31-34 \%$ in the cited publications. ADF and NDF contents were similar to data concerning other Polish cultivars. It is worth drawing attention to the distinctly higher content of $\mathrm{Cu}, \mathrm{Zn}, \mathrm{Mn}$ in cv. Boruta than in Emir, Sur, Saturn and Polonez cultivars and the lower total amounts of oligosaccharides compared to data reported by Mosenthin 
(2001). The alkaloid content was typical for sweet lupine (Petterson and Mackintosh, 1994).

In comparison with narrow-leaved lupine, yellow lupine cv. Mister contains more protein, fiber fractions, more methionine and lysine, phosphorus and $\mathrm{Fe}$, but clearly lower amounts of $\mathrm{Mn}$ and total alkaloids. The oligosaccharide level in both lupine cultivars was relatively similar; however, the verbascose share in total oligosaccharides was about $30 \%$ higher in yellow than in narrow-leaved lupine.

The protein content in pea cv. Muza amounted to $27.6 \%$ and was higher than values given by Pettersen and Mackintosh (1994). The concentration of oligosaccharides was a little lower than in lupine seeds, although the verbascose share in total oligosaccharides was two times higher than in narrow-leaved and $25 \%$ higher than in yellow lupine.

In our own study, a mixture of narrow-leaved and yellow lupine and pea seeds was used in layer diets instead of soybean meal. By the inclusion of about $19.46 \%$ of these legumes and $8 \%$ rapeseed in diets, it was possible to obtain positive effects in the laying rate and feed intake; however, a decrease of egg weight and poorer FCR ( $\mathrm{kg} / \mathrm{kg}$ egg weight) indices were also recorded. Further increase of legume content to $27.68 \%$ (yellow lupine from $2.3 \%$ in diet II to $12 \%$ in diet III) caused a significant decrease in the performance in comparison with the control (by about 7-8\%) after nine weeks of experiment. The lower egg weight was registered already after 4 weeks of the use of experimental diets for layers. Egg weight (1-17 weeks of experiment) was negatively affected in experimental treatments. This result was similar to the findings of Hammershøj and Steenfeldt (2005); 25\% content of narrow-leaved lupine in hen feed lowered egg production, egg weight and also reduced feed intake were noted. The level of $15 \%$ of lupine in the hen diet did not have negative effects. In our study, increased content of legume seeds in diets for hens led to a decrease in egg weight, egg shell share in the egg and shell thickness. Moreover, greater changes in egg quality were observed as a result of time of feeding of experimental diets. After 13 weeks, yolk colour and shell thickness in egg from hens fed the diet with $27.68 \%$ of legumes were better than after 5 weeks.

Nalle et al. (2011) did not observe any decrease by feeding broilers with diets containing 20\% of narrow-leaved lupine. McNeill et al. (2004) reported that the inclusion of $10 \%$ peas exerted only a small influence on feed intake and broiler growth; higher content of peas $(20 \%)$ reduced the feed intake. Castano and Perez-Lanzac (1990) found a significant negative relationship between dietary concentrations of legumes and feed intake, egg production and feed to egg ratio.

The results obtained in our study suggest that the presence of antinutritive substances in investigated legume seeds negatively affects feed intake. This is clearly seen in the case of high content of yellow lupine (diet III).

It is still difficult to explain these effects on the basis of chemical characteristics of complete diets, all the more that the feed mixture compositions were optimized by taking into consideration many nutrients. Dietary fiber or alkaloid fractions may partly explain the results obtained. But the total $\alpha$-galactosides content in yellow lupine cv. Mister was similar to data presented by Martinez-Villauenga et al. (2006). Moreover, the stachyose level in yellow lupine cv. Mister was significantly lower 
$(4.9 \mathrm{mg} / \mathrm{g})$ than its levels presented by the cited authors $(7-8 \mathrm{mg} / \mathrm{g})$. Probably, the observed worse results can be attributed to the response of hens - mainly in treatment III - to the complex of harmful substances present in about $27.68 \%$ content of the used legume seeds. In conclusion, the use of about $27.68 \%$ of legume seed in laying hen diet affected negatively performance results but about $19.48 \%$ of these seeds in diets could be accepted as a soybean meal substitute.

\section{References}

AOAC (2007). Official Methods of Analysis of the Association Official Analytical Chemists. 18th Edition, Arlington USA.

B u ckeridg e M.S., P e s s o a dos S an to s H., Tine M.A.S. (2000). Mobilisation of storage cell wall polysaccharides in seeds. Plant Physiol. Bioch., 23: 141-156.

Cast a n on J.I.R., P e re z- L a n z a c J. (1990). Substitution of fixed amounts of soybean meal for field beans (Vicia faba), sweet lupins (Lupinus albus), cull peas (Pisum sativum) and vetches (Vicia sativa) in diets for high performance laying Leghorn hens. Brit. Poultry Sci., 31: 173-180.

Diaz D., Morlacchini M., Masoero F., Moschini M., Fuschoni G., Gianfranc o P. (2005). Pea seeds (Pisum sativum), faba beans (Vicia faba var. Minor) and lupin seeds (Lupinus albus var. Multitalia) as protein sources in broiler diets: effect of extrusion on growth performance. Ital. J. Anim. Sci., 5: 43-53.

D uranti M. (2006). Grain legume proteins and nutraceutical properties. Fitoterapia, 77: 67-82.

E rd e m o u g 1 u N., O z k a n S. (2007). Alkaloid profile and antimicrobial activity of Lupinus angustifolius L. alkaloid extract. Phytochem. Rev., 6: 197-201.

Fru-Nj i F., Ni e s s E., P fe ffer E. (2007). Effect of graded replacement of soybean meal by faba beans (Vicia faba L.) or field peas (Pisum sativum L.) in rations for laying hens on egg production and quality. J. Poult. Sci., 44: 34-41.

Guillamon E., Pedrosa M.M., B urbano C., Cuadrado C., de Cortes Sanchez M., Mu zquiz M. (2008). The trypsin inhibitors present in seed of different grain legume species and cultivar. Food Chem., 107: 68-74.

$\mathrm{H}$ a $\mathrm{m} \mathrm{m}$ e $\mathrm{rsh} \varnothing \mathrm{j}$ M., S t e e $\mathrm{n}$ e $1 \mathrm{~d} \mathrm{t}$ S. (2005). Effects of blue lupin (Lupinus angustifolius) in organic layer diets and supplementation with foraging material on egg production and some egg quality parameters. Poultry Sci., 84: 723-733.

Hughes R.J., Kocher A. (1998). Nutritive value of lupins for layers. Proc. Australian Poultry Science Symposium, Sydney, University of Sydney, 10: 140-143.

$\mathrm{I} g \mathrm{~b}$ a s a n F.A., G u e $\mathrm{n}$ t e $\mathrm{r}$ W. (1997). The influence of micronization, dehulling and enzyme supplementation on the nutritional value of peas for laying hens. Poultry Sci., 76: 331-337.

J a m r o z D., K u b i z n a J. (2008). Harmful substances in legume seeds - their negative and beneficial properties. Pol. J. Vet. Sci., 11: 389-404.

J u 1 L.B., F 1 e n g mark P., Gylling M., Itenov K. (2003). Lupin seed (Lupinus albus and Lupinus luteaus) as a protein source for fermentation use. Ind. Crop. Prod., 18: 199-121.

La mpart-Szczapa E., Korczak J., Nog a la - Kalucka M., Zawirska-Wojtasiak R. (2003). Antioxidant properties of lupin seed products. Food Chem., 83: 279-285.

L a ud adio V., Tu fare 11 i V. (2011). Influence of substituting dietary soybean meal for dehulledmicronized lupin (Lupinus albus cv. Multitalia) on early phase laying hens production and egg quality. Liv. Sci., 140: 184-188.

La u dadi o V., Tu fare 11 i V. (2012). Effect of treated field pea (Pisum sativum L. cv Spirale) as substitute for soybean extracted meal in a wheat middlings-based diet on egg production and quality of early laying brown hens. Arch. Geflugelkd., 76: 1-5.

Martinez-Villaluenga C., Frias J., Vidal-Valverde C. (2006). Functional lupin seeds (Lupinus albus L. and Lupinus luteus L.) after extraction of $\alpha$-galactosides. Food Chem., 98: 291-299. 
M c N e ill L., B e rn ard K., M a c l e o d M.J. (2004). Food intake, growth rate, food conversion and food choice in broilers fed on diets high in rapeseed meal and pea meal with observation on sensory evaluation of the resulting poultry meat. Brit. Poultry Sci., 45: 519-523.

Mieczkowska A., Jansmann A.J.M., Kwakkel R.P., Smulikowska S. (2004). Effect of dehulling and $\alpha$-galactosidase supplement on the ileal digestibility of yellow lupin based diets in broiler chickens and adult roosters. J. Anim. Feed Sci., 14: 297-304.

Mikulski D., Jankowski J., Zduńczyk Z., Juśkiewicz J., Słomiński B.A. (2012). The effect of different dietary levels of rapeseed meal on growth performance, carcass traits, and meat quality in turkeys. Poultry Sci., 91: 215-223

M o s e $\mathrm{n}$ th in R. (2001). Digestion resistant oligosaccharides in swine nutrition (in Poland). Prz. Hod., 2: $2-6$.

Nalle C.L., Ravindran V., Ravindran G. (2011). Nutritional value of narrow-leafed lupin (Lupinus angustifolius) for broilers. Brit. Poultry Sci., 52: 775-781.

Orda J., Jamroz D., Wiliczkiewicz A., Wertelecki T., Skorupińska J., Broz J. (2006). Effects of increased dietary inclusion of yellow lupins and enzyme supplementation on performance, ileal digestibility of nutrients and microbial status of large intestine in broiler chickens. Arch. Geflügelk., 70: 14-21.

P e r e z - M a l d o n a d o R.A., M a n n i o n P.F., F a r r e l D.J. (1999). Optimum inclusion of field peas, faba beans, chick peas and sweet lupins in poultry diets. 1. Chemical composition and layer experiments. Brit. Poultry Sci., 40: 667-673.

Petterson D.S., Mackintosh J.B. (1994). The chemical composition of lupin seed grown in Australia. Proc. First Australian Lupin Technical Symp., Perth, pp. 38-48.

PN-R-64784:1994 Determination of the sugars content.

Rutkowski A., Kaczmarek S., Szczyrkowska A., Józefiak D. (2012). The effect of particle size of full-fat rapeseed and of multi-carbohydrase enzyme supplementation on nutrient digestibility and performance in broilers. J. Anim. Feed Sci., 21: 324-333.

S a n d b e r g A.S. (2002). Bioavailability of minerals in legumes. Brit. J. Nutr., 88: Sup. 3: 281-285.

S mulikowska S., Rutkowski A. (2005). Editors. Recommended Allowances and Nutritive Value of Feedstuffs - Poultry Feeding Standards (in Polish). 5th Edition, The Kielanowski Institute of Animal Physiology and Nutrition, Jabłonna (Poland).

Sujak A., Kotlarz A., Strobel W. (2006). Compositional and nutritional evaluation of several lupin seeds. Food Chem., 98: 771-719.

Św i ą t ki ew i c z S., A r c z e w s k a - Włos e k A. (2011). Prospects for the use of genetically modified crops with improved nutritional properties as feed materials in poultry nutrition. World. Poultry Sci. J., 67: 631-642.

Viveros A., Centeno C., Arija I., Brenes A. (2007). Cholesterol-lowering effects of dietary lupin (Lupinus albus var Multolupa) in chicken diets. Poultry Sci., 86: 2631-2638.

Wa si lew k o J., B u r a c zew s k a L. (1999). Chemical composition including content of amino acids, minerals and alkaloids in seeds of three lupin species cultivated in Poland. J. Anim. Feed Sci., 8: $1-12$.

Zal ew s ki K., L a hut a L.B., H or b ow i c z M. (2001). The effect of soil drought on the composition of carbohydrates in yellow lupine seeds and triticale kernels. Acta Physiol. Plant., 23: 73-78.

Z d uń c z y k Z., G o d y c k a I., A m a r o w i c z R. (1996). Chemical composition and content of antinutritional factors in Polish cultivars of peas. Plant Food Hum. Nutr., 50: 37-45.

Zduńczy k Z., J uśki e w i c z J., Frejn ge 1 S., Gulewi c z K. (1998). Influence of alkaloids and oligosaccharides from white lupin seeds on utilization of diets by rats and absorption of nutrients in the small intestine. Anim. Feed Sci. Technol., 72: 143-154.

Received: 30 I 2014

Accepted: 15 VII 2014 